\title{
PENGARUH PERAWAT TERHADAP KEJADIAN MEDICATION \\ ERROR DI RUMAH SAKIT
}

\author{
Januarizkah Napitu \\ januarizkahnapitu@gmail.com
}

\section{LATAR BELAKANG}

Keselamatan pasien menjadi isu yang penting di dunia perumahsakitan dan menjadi inti dari pelayanan yang berfokus pada pasien bersama-sama dengan peningkatan mutu. : Mengurangi kejadian medication error akan secara signifikan meningkatkan keselamatan pasien dan kualitas penggunaan obat-obatan. Keselamatan pasien merupakan suatu disiplin baru dalam pelayanan kesehatan yang mengutamakan pelaporan, analisis, dan pencegahan medical error yang sering menimbulkan Kejadian Tak Diharapkan (KTD) dalam pelayanan kesehatan. Kegiatan skrining resep yang dilakukan tenaga kefarmasian untuk mencegah terjadinya keselahan pengobatan (Medication error). Berdasarkan Laporan Peta Nasional Keselamatan Pasien (Kongres PERSI 2007) kesalahan dalam pemberian obat menduduki peringkat pertama $(24,8 \%)$ dari 10 besar insiden yang dilaporkan (Kemenkes, 2008). Medication error adalah kejadian yang idealnya dapat dicegah pada waktu pengobatan yang dapat menyebabkan atau mengarah pada penggunaan obat yang tidak sesuai atau membahayakan bagi pasien saat pengobatan berada di bawah pengawasan profesi pelayanan kesehatan, atau pasien sendiri. (NCCMERP, 2017). Medication error dibedakan menjadi 3 jenis berdasarkan tahap pengobatan, yaitu : prescribing error (resep tidak terbaca, data pasien tdak lengkap, nama obat yang tidak jelas), dispensing error (bentuk sediaan yang tidak tepat, obat kadaluarsa, instruksi obat yang tidak tepat), dan administration error (kesalahan waktu pemberian obat, dosis tidak tepat, teknik atau rute pemberian obat yang salah).

Saat ini medication error menjadi salah satu permasalahan kesehatan yang banyak menimbulkan berbagai dampak bagi pasien mulai dari resiko ringan bahkan resiko yang paling parah yaitu menyebabkan suatu kematian. Di Indonesia, prevalensi medication error berdasarkan data nasional kesalahan pemberian obat menduduki peringkat pertama sebesar 24,8\% dari 10 besar insiden di rumah sakit yang pernah dilaporkan. Tahap dispensing adalah urutan pertama kesalahan dalam proses penggunaan obat. Pada penelitian di ruang perawatan pasien di RS Charitas Palembang (Simamora, 2011). Kejadian Tidak Diinginkan yang 
berhubungan dengan penggunaan obat sebanyak 76 kasus $(26 \%)$ dan dari seluruh kejadian ini medication error yang paling sering terjadi adalah pada fase administration $81,32 \%$, fase prescribing 15,88 \% dan fase transcribing 2,8\%.5 . Menurut National Patient Safety Agency (2004), medication error pada tahap administration error adalah jenis kesalahan yang paling sering terjadi dan menimbulkan dampak yang paling parah dibandingkan jenis kesalahan lainnya. Pihak yang paling bertanggung jawab dalam tahap drug administration adalah perawat, sebab perawat berkewajiban dalam tindakan pemberian obat.

\section{METODE}

Metode yang saya gunakan dalam membuat artikel ini disebut literasi. Saya membaca beberapa informasi dari berbagai sumber referensi berupa buku, dan jurnal. Melalui metode inilah saya memahami dan mengidentifikasi isu yang terkait dengan keselamatan pasien, saya mengambil tema tentang medical error untuk judul penelitian saya, dan mengidentifikasi peran perawat terhadap kejadian medication error.

\section{HASIL}

Seorang perawat adalah penghubung utama antara pasien dan obat yang akan masuk ketubuh pasien, hal ini berarti bahwa perawat tidak hanya memiliki keterampilan dalam memberikan obat sesuai dengan kebutuhan pasien, melainkan juga bertanggung jawab untuk menangkap kesalahan dalam perintah sebelum memberikan obat (Matsumoto, 2008).

Keterampilan perawat dalam pemberian obat dengan memperhatikan prinsip benar obat, benar pasien, benar dosis, benar waktu pemberian benar tehnik pemberian dan prinsip benar pemberian obat lainnya, memegang peranan yang penting dalam medication error. Jika salah satu dari prinsip tersebut salah dilakukan maka dapat berpotensi menimbulkan medication error dan merugikan pasien yang berakibat pada perpanjangan hari perawatan.

ASHP guidelines on preventing medication erros in hospital (2003) menyampaikan bahwa, kurangnya pengetahuan perawat merupakan salah satu faktor yang mempengaruhi medication error. Hasil penelitian tersebut sejalan dengan penelitian yang dilakukan oleh Yunus (2013) yang menjelaskan bahwa ruang perawatan dengan pengetahuan perawat yang baik, angka kejadian kesalahan pengobatannya semakin kecil. Dalam penelitian tersebut juga 
menyimpulkan bahwa terdapat hubungan antara pengetahuan perawat dengan kesalahan pengobatan. Begitu juga dengan penelitian yang dilakukan oleh Amik (2014) yang menjelaskan bahwa perawat dengan pengetahuan yang baik lebih sedikit melakukan kesalahan dalam pengobatan, serta lebih bisa mengidentifikasi kesalahan pengobatan sebelum kesalahan tersebut mencapai pasien.

Komunikasi yang efektif antara perawat dengan pasien merupakan kunci dari patient safety (WHO, 2008). Berdasarkan sebuah studi yang disampaikan dalam artikel WHO "learning form error" (2008), didapatkan bahwa lebih dari 60\% error yang terjadi disebabkan oleh kurangnya komunikasi. ASHP Guidelines on Preventing medication error in Hospital (2003) menyampaikan bahwa, kurangnya komunikasi antara perawat dengan pasien berpotensi menyebabkan kejadian medication error. Lebih lanjut dijelaskan bahwa, salah satu peran perawat dalam pencegahan medication error adalah perawat wajib untuk menginformasikan segala sesuatu yang berkaitan dengan diagnosa dan informasi seputar pengobatan pasien. Seorang perawat dapat menciptakan suasana kemitraan yang baik dengan menyediakan cukup waktu untuk berdialog dan berkonsultasi dengan pasien.

\section{PEMBAHASAN}

\section{A. Medication Error}

Medication error adalah suatu kejadian yang tidak hanya dapat merugikan pasien tetapi juga dapat membahayakan keselamatan pasien yang dilakukan oleh petugas kesehatan khususnya dalam hal pelayanan pengobatan pasien. Medication error dapat menyebabkan efek samping yang membahayakan dan dapat memicu resiko fatal dari penyakit, sehingga secara tidak langsung medication error dapat menyebabkan kerugian bagi pasien berupa perpanjangan hari perawatan.

Adapun tahap-tahap medication error sebagai berikut :

\section{Prescribing error}

Prescribing error adalah kesalahan yang terjadi selama proses peresepan obat. Tulisan resep yang tidak jelas ini pun akan sangat berdampak pada tahap selanjutnya. Penulisan bentuk sediaan dalam resep diperlukan. Hasil penelitian dari jurnal yang ditulis oleh Andy Theory Bayang, dkk berjudul "faktor penyebab 
medication error di rsud anwar makkatutu kabupaten bantaeng", menunjukkan bahwa tidak adanya bentuk sediaan $74,53 \%$ dan memiliki potensi terjadinya Medical error. Tidak adanya bentuk sediaan ini sangat merugikan pasien. Pemilihan bentuk sediaan ini disesuaikan dengan kondisi pasien. Dosis atau takaran suatu obat adalah banyaknya suatu obat yang dapat dipergunakan atau diberikan kepada seseorang penderita untuk obat dalam maupun obat luar. Oleh karena itu, dosis merupakan bagian yang sangat penting dalam resep.

\section{Dispensing error}

Dispensing error adalah kesalahan yang terjadi selama proses peracikan obat meliputi content errors dan labelling errors. Contoh yang biasa terjadi adalah tidak dilakukan pengamatan ratarata waktu pemberian informasi obat sebab sebagian besar sediaan farmasi yang disiapkan bagi pasien ICU adalah sediaan injeksi, sehingga tidak ada pemberian informasi obat oleh farmasis dengan pertimbangan bahwa informasi obat telah diketahui oleh para perawat di ruang ICU.

\section{Administration errors}

Administration error adalah kesalahan yang terjadi selama proses pemberian obat kepada pasien meliputi kesalahan teknik pemberian, rute, waktu, salah pasien. Pengelolaan obat secara tidak langsung berpengaruh terhadap proses pemberian obat kepada pasien. Adanya kekosongan obat dapat menjadi faktor penyebab lambatnya obat diberikan kepada pasien. Administration error yang lain berupa teknik pemberian obat yang tidak tepat, ada obat yang seharusnya di encerkan terlebih dahulu, tetapi diberikan secara injeksi langsung. Hal ini tentu saja berakibat fatal pada diri pasien. Dalam penelitiannya, Fitriani (2010) menyatakan bahwa jenis medication error yang terjadi selama tahun 2009 adalah salah waktu minum obat (20.9\%), Interval waktu pemberian obat tidak tepat (13.4\%) dan Pemberian obat yang tidak rasional (12.4\%). salah perhitungan dosis $(11,7 \%)$, salah membaca resep (salah obat) (10,4\%), salah penyerahan obat (salah pasien) $(8.46 \%)$.

\section{B. Faktor- faktor Penyebab Medication Error}

Faktor penyebab dari medication error dapat berupa:

1) Komunikasi yang buruk, baik secara tertulis (dalam resep) maupun secara lisan (antar pasien, dokter dan pasien). 
2) Sistem distribusi obat yang kurang mendukung (sistem komputerisasi, sistem penyimpanan obat, dan lain sebagainya).

3) Sumber daya manusia (kurang pengetahuan, pekerjaan yang berlebihan).

4) Edukasi kepada pasien kurang.

5) Peran pasien dan keluarganya kurang (Cohen 1991).

Leape, et. Al (1995) mengidentifikasi penyebab kesalahan pengobatan antara lain :

1) Kurangnya diseminasi pengetahuan, terutama para dokter yang merupakan $22 \%$ penyebab kesalahan,

2) Tidak cukupnya informasi, 14\% dari kesalahan mengenai pasien seperti halnya data uji laboratorium,

3) Sebanyak 10\% kesalahan dosis yang kemungkinan disebabkan oleh tidak diikutinya SOP pengobatan,

4) $9 \%$ Lupa,

5) $9 \%$ kesalahan dalam membaca resep seperti tulisan tidak terbaca, interpretasi perintah dalam resep, dan singkatan dalam resep,

6) Salah mengerti perintah lisan,

7) Pelabelan dan kemasan,

8) Stok dan penyimpanan obat yang tidak baik,

9) Masalah dengan standar dan distribusi,

10) Assesment alat penyampai obat yang tidak baik saat membeli dan penggunaan,

11) Stress di lingkungan kerja, dan

12) Ketidaktahuan pasien.

Demikian pula dengan medication error dapat terjadi karena lingkungan pekerjaan perawat yang kurang mendukung, tingkat jabatan perawat, rekonsiliasi obat pra-masuk dan keluar rumah sakit, kurangnya pengetahuan tentang obat-obatan (dosis, mendeteksi interaksi obat), pengkajian yang kurang lengkap tentang riwayat alergi dan kurangnya pemantauan klinis. Kejadian Medication error juga terkait dengan praktisi, produk obat, prosedur, lingkungan atau sistem (Rusmi dkk., 2012). Kesalahan pada salah satu tahap dapat terjadi secara berantai dan menimbulkan kesalahan pada tahap selanjutnya. Dalam praktek seharihari, karena kondisi pasien sedang banyak dan kmpleksitas kondisi kesehatan pasien, terkadang membuat pelanggaran prosedur yang dilakukan petugas, seperti seorang Dokter melewatkan pengecekan kebenaran identitas psien, tidak mengecek kondisi alergi pasien 
serta tidak mengecek obat apa yang dipakai oleh pasien sebelumnya(rekonsiliasi). Sedangkan seorang petugas farmasi karena kesibukannya melakukan kesalahan pelanggaran prosedur dengan tidak sempat mengecek kebenaran identitas pasien pada catatan pemberian obat pasien, tidak sempat melengkapi data obat tambahan yang diminta lewat telepon oleh perawat sehingga terjadi Medication error, atau petugas farmasi tidak sempat mengecek kebenaran kebenaran keterangan etiket obat yang telah dibuatnya dan tidak menyim obat kemoterapi pasien untuk hari lanjutan.

Penyebab Medication Error Hal yang dapat menyebabkan medication error adalah miskomunikasi antara dokter dan farmasis yang dapat berupa penulisan resep yang tidak jelas, nama obat yang mirip, aturan pakai yang tidak jelas, pemberian obat pada pasien dengan rute dan teknik pemberian yang tidak tepat. penyebab prescribing error adalah faktor lingkungan kerja, faktor petugas kesehatan, dan faktor pasien. Penyebab dispensing error adalah faktor prosedur pengelolaan obat, faktor lingkungan kerja, faktor petugas kesehatan, dan faktor pasien. Penyebab administration error adalah faktor petugas kesehatan, faktor lingkungan kerja, dan faktor pasien.

\section{Pencegahan Medication Error}

Untuk mencegah terjadinya medication error diperlukan kerjasama antar Pelaksana Program pencegahan medication error (PIP) oleh tim multidisiplin. Lingkungan praktek yang mendukung akan membuat efek posistif diantara perawat, adanya kerjasama dan komunikasi yang baik antar perawat pada saat praktek akan menurunkan tingkat terjadinya medication error (Flynn Linda, et al, 2012).

Sehubungan dengan hal tsb., ada tiga cara yang dinyatakan dapat mencegah medication error yaitu:

1) Penulisan resep oleh dokter secara komputerisasi (76\%).

2) Ward clinical pharmacist (81\%).

3) Peningkatan komunikasi antar dokter, apoteker/perawat dan pasien (86\%) (Fortescue et al, 2003).

Strategi Pencegahan yang harus dilakukan adalah: 


\section{1) Optimasi Proses Penggunaan}

a. Peresepan: pembakuan penulisan resep, peresepan elektronik, clinical decision support systems.

b. Transkripsi: catatan medik elektronik.

c. Peracikan: bar code technology.

d. Pemberian: pengecekan ulang, penggunaan pompa suntik/ infus.

e. Medication reconciliation : kesalahan penggunaan obat sering terjadi pada penderita penyakit kronik yang menjalani pindah rawat, misalnya dari Rawat jalan, IGD, ICU, bangsal.

2) Dinyatakan sebagai kesalahan bila ada ketidaksesuaian antara obat yang selama ini digunakan dengan obat yang diberikan sewaktu pindah rawat secara tak sengaja, dan berpotensi timbulkan cidera. Ketaksesuaian itu meliputi penghentian obat lama, pemberian obat baru yang alergenik, pemberian obat yang sama tetapi beda dosis/ frekuensi/ cara pemberian, dll.

\section{Hubungan Pengetahuan Perawat Dengan Kejadian Medication error}

Pengetahuan yang dimaksud dalam penelitian ini adalah pengetahuan perawat mengenai medication error dan pemberian obat. Aspek pengetahuan yang dikaji antara lain : Definisi medication error, Pencegahan medication error, Akibat yang ditimbulkan karena medication error, pengkajian yang dilakukan dalam pemberian obat,Prinsip benar pemberian obat, Rute pemberian obat dan beberapa pertanyan lain seputar pemberian obat dan medication error.

ASHP guidelines on preventing medication erros in hospital (2003) menyampaikan bahwa, kurangnya pengetahuan perawat merupakan salah satu faktor yang mempengaruhi medication error. Hasil penelitian tersebut sejalan dengan penelitian yang dilakukan oleh Yunus (2013) yang menjelaskan bahwa ruang perawatan dengan pengetahuan perawat yang baik, angka kejadian kesalahan pengobatannya semakin kecil. Dalam penelitian tersebut juga menyimpulkan bahwa terdapat hubungan antara pengetahuan perawat dengan kesalahan pengobatan. Begitu juga dengan penelitian yang dilakukan oleh Amik (2014) yang menjelaskan bahwa perawat dengan pengetahuan yang baik lebih sedikit melakukan 
kesalahan dalam pengobatan, serta lebih bisa mengidentifikasi kesalahan pengobatan sebelum kesalahan tersebut mencapai pasien

\section{Hubungan Keterampilan Perawat Dengan Kejadian Medication error}

Melakukan pemberian obat adalah tanggung jawab terbesar bagi perawat di Rumah Sakit, oleh karena itu perawat harus menggali dan memahami tentang keterampilan apa yang harus dikembangkan guna memberikan pelayanan yang baik (Matsumoto, 2008).

Keterampilan yang dimaksud dalam penelitian ini adalah keterampilan perawat dalam pemberian obat. Aspek keterampilan perawat dikaji dengan menggunakan indikator 12 benar pemberian obat dan tindakan persiapan pra pemberian obat.

Seorang perawat adalah penghubung utama antara pasien dan obat yang akan masuk ketubuh pasien, hal ini berarti bahwa perawat tidak hanya memiliki keterampilan dalam memberikan obat sesuai dengan kebutuhan pasien, melainkan juga bertanggung jawab untuk menangkap kesalahan dalam perintah sebelum memberikan obat (Matsumoto, 2008). Keterampilan perawat dalam pemberian obat dengan memperhatikan prinsip benar obat, benar pasien, benar dosis, benar waktu pemberian benar tehnik pemberian dan prinsip benar pemberian obat lainnya, memegang peranan yang penting dalam medication error. Jika salah satu dari prinsip tersebut salah dilakukan maka dapat berpotensi menimbulkan medication error dan merugikan pasien yang berakibat pada perpanjangan hari perawatan.

\section{E. Hubungan Komunikasi Perawat Dengan Kejadian Medication error}

Komunikasi perawat yang dimaksud dalam penelitian ini adalah komunikasi perawat dengan pasien pada saat tindakan pemberian obat dilakukan. Komunikasi perawat kepada pasien menggambarkan bagaimana perawat tersebut memberikan informasi mengenai efek samping obat, jadwal pemberian obat, cara pemberian obat, memastikan pemahaman informasi, dan memberikan jawaban atas semua pertanyaan pasien seputar obat-obatan yang akan ia terima

Komunikasi yang efektif antara perawat dengan pasien merupakan kunci dari patient safety (WHO, 2008). Berdasarkan sebuah studi yang disampaikan dalam artikel WHO "learning form error" (2008), didapatkan bahwa lebih dari 60\% error yang terjadi disebabkan oleh kurangnya komunikasi. ASHP Guidelines on Preventing medication error in Hospital (2003) menyampaikan bahwa, kurangnya komunikasi antara perawat dengan pasien berpotensi menyebabkan kejadian medication error. Lebih lanjut dijelaskan bahwa, salah satu 
peran perawat dalam pencegahan medication error adalah perawat wajib untuk menginformasikan segala sesuatu yang berkaitan dengan diagnosa dan informasi seputar pengobatan pasien. Seorang perawat dapat menciptakan suasana kemitraan yang baik dengan menyediakan cukup waktu untuk berdialog dan berkonsultasi dengan pasien.

\section{PENUTUP}

Seorang perawat adalah penghubung utama antara pasien dan obat yang akan masuk ketubuh pasien, hal ini berarti bahwa perawat tidak hanya memiliki keterampilan dalam memberikan obat sesuai dengan kebutuhan pasien, melainkan juga bertanggung jawab untuk menangkap kesalahan dalam perintah sebelum memberikan obat (Matsumoto, 2008). ASHP guidelines on preventing medication erros in hospital (2003) menyampaikan bahwa, kurangnya pengetahuan perawat merupakan salah satu faktor yang mempengaruhi medication errorr dan Komunikasi yang efektif antara perawat dengan pasien merupakan kunci dari patient safety (WHO, 2008).

\section{REFERENSI :}

1. Bangun K, Dewi S., \& Kusumanto H. (2019). Faktor-Faktor Yang Mempengaruhi Perilaku Perawat Dalam Melaksanakan Keselamatan Pasien Terkait Pemberian Obat Di Ruang Perawatan RS PGI Cikini Tahun 2018. Jurnal Manajemen dan Administrasi Rumah Sakit Indonesia Vol. 3 No. 1

2. Budihardjo, Vidia Sabrina. (2017). Faktor Perawat Terhadap Kejadian Medication Administration Error Di Instalasi Rawat Inap. Jurnal Administrasi Kesehatan Indonesia Vol. 5 No. 1

3. Gloria, Lulu., \& Yuwono., Ngudiantoro. (2017). Analisis Faktor Yang Mempengaruhi Medication Error Pada Pasien Kemoterapi Di RSUP DR. Mohammad Hoesin Palembang. Majalah Kedokteran Sriwijaya, Th. 49 No. 4 
4. Handayani, Tien Wahyu. (2017). Faktor Penyebab Medication Error Di RSU Anutapura Kota Palu. Perspektif: Jurnal Pengembangan Sumber Daya Insani Vol. 2 No. 2

5. Hartati., Lolok, Nike Herpianti., Fudholi, Achmad., \& Satib. (2014). Analisis Kejadian Medication Error Pada Pasien ICU. Jurnal Manajemen dan Pelayanan Farmasi Vol. 4 No. 2

6. Indriani, Siti., Ningrum, Bhekti Setya., \& Haryati, Rr. Tutik Sri. (2019). Penggunaan Electronic Medication Management (EMM) Dalam Menurunkan Kejadian Medication Error Di Keperawatan. SURYA Vol. 11 No. 03

7. Khairurrijal, M. A W., \& Putriana, Norisca Aliza. (2017). Review : Medication Erorr PadaTahap Prescribing, Transcribing, Dispensing, Dan Administration. Majalah Farmasetika, Vol. 2 No. 4

8. Oktarlina, Rasmi Zakiah., \& Wafiyatunisa, Zahra. (2017). Kejadian Medication Error Pada Fase Prescribing Di Poliklinik Pasien Rawat Jalan RSD Mayjend HM Ryacudu Kotabumi. JK Unila Vol. 1 No. 3

9. Simamora, R. H., \& Nurmaini, C. T. S. (2019). Knowledge of Nurses about Prevention of Patient Fall Risk in Inpatient Room of Private Hospital in Medan. Indian Journal of Public Health Research \& Development, 10(10), 759-763.

10. Timbongol, Chintia., Lolo, Widya Astuty., \& Sudewi, Sri. (2016). Identifikasi Kesalahan Pengobatan (Medication Error) Pada Tahap Peresepan (Prescribing) Di Poli Interna RSUD Bitung. PHARMACON Jurnal Ilmiah Farmasi-UNSRAT Vol. 5 No. 3

11. Waluyo, Kiaonarni Ongko. (2015). Medication Error Dalam Keperawatan. Jurnal Keperawatan Vol. 8 No. 3 